\title{
Ethics and principles of Polish journalists. Quantitative and qualitative research.
}

\section{ABSTRACT}

This article contains the results of research conducted among Polish journalists. More than 200 reporters, editors, and media workers answered 40 questions concerning ethical standards and practices. The main conclusion of the survey is that journalists are strongly divided in terms of how to understand and fulfil the norms written in the Press Law Act and codes of ethics. The complementary qualitative study (in-depth interviews) proves that the main reasons for lowering professional standards are the politicization and commercialization of the media, as well as the technological progress. The results of the research described in this article were primarily published in the Polish language as part of my Ph.D. dissertation. A full description of the research with a literature review and a theoretical background is available online and in the print version of my peer-reviewed book "Dziennikarzy portret własny" $^{\prime 1}$

\section{Background}

\section{Socially responsible press}

It has been almost 80 years since the American society realised that unfettered freedom of the owners of the media companies does not guarantee real freedom of the press. Due to great criticism from the public and government over media ownership, a group of scholars in

\footnotetext{
${ }^{11}$ You can find more details on the publisher website www.libron.pl or on my ResearchGate profile: https://www.researchgate.net/profile/Michal Chlebowski, Chlebowski M. (2020), Dziennikarzy portret własny, Libron, Warsaw.
} 
Ethics and principles of Polish journalists. Quantitative and qualitative research.

1943 formed the Commission on Freedom of the Press, chaired by University of Chicago president Robert Maynard Hutchins ${ }^{2}$. Members of the Commission prepared the final report where they gave ground for the Social Responsibility Theory of the Press. The Commission listed five things that modern society requires of its press ${ }^{3}$.

- The press needs to provide a truthful, comprehensive and intelligent account of the day's events in a context which gives them meaning.

- The press should serve as a forum for the exchange of comment and criticism.

- The press needs to project a representative picture of the constituent groups in society

- The press is responsible for "the presentation and clarification of the goals and values of the society"

- The press should provide full access to the day's intelligence ${ }^{4}$.

The main assumption of the theory is that "the power and near-monopoly position of the media impose on them an obligation to be socially responsible, to see that all sides are fairly presented and that public has enough information to decide; and that if the media do not take on themselves such responsibility it may be necessary for some other agency of the public to enforce $\mathrm{it}^{\prime \prime}$. Members of the Commission did not put much faith in the efficacy of selfregulation of the media. They thought that the government must protect the freedom of expression, but it also must protect society from the irresponsible media owners. That is the reason why standards of journalism shall be regulated equally by the law and by the codes of ethics. Ten years after the publication of the Commission's report, the paradigm of the Social Responsibility was described as one of "Four Theories of the Press" in the fundamental book written by Fred S. Siebert, Theodore Peterson and Wilbur Schramm. This concept of a normative theory of the press had a powerful impact on the scholarship and despite some criticism does not have a better replacement so far. After more than 60 years, the Social Responsibility Theory is still a paradigm of media functioning in democratic countries.

\footnotetext{
2 Bates S. (2018), Media Censures: The Hutchins Commission on the Press, the New York Intellectuals on Mass Culture, International Journal of Communication vol. 12 , pp. 4784-4801.

${ }^{3}$ Siebert F., Peterson T., Schramm W. (1956), Four Theories of the Press, University of Illinois Press, Chicago.

${ }^{4}$ Ibidem.

${ }^{5}$ Ibidem p. 5.
} 
Ethics and principles of Polish journalists. Quantitative and qualitative research.

\section{Poland: from Communist to the Social Responsibility Media Theory}

Before 1989, the Polish media system was similar to the Soviet Communist concept. Almost all of the media ${ }^{6}$ were controlled and censored by the government. The main goal of its existence was to enforce the ruling party. When Communism fell, the Polish media system changed. According to the main thesis of the "Four Theories of the Press" the press always takes on the form and colouration of the social and political structures within which it operates $^{7}$. Polish media are clear evidence of the truthfulness of this thought.

After 1989, Poland went through the process of democratization. The Parliament has accepted the new constitution, guaranteeing the freedom of the media. The previous Communist press law was changed to allow the existence of private media companies and free publishing. In the following years, there was a rapid rise of new media companies and numbers of journalists. Some studies show that the estimated number of journalists in Poland rose from 11000 in the year 1990 to 18000 in $2000^{8}$. At the same time, Polish journalists, editors and publishers have struggled to establish new rules of self-regulation. In 1994, the representatives of public and private media companies signed a document called "Media Ethics Charter" (org. Karta Etyczna Mediów). The Charter consists of seven principles: truth, objectivity, the distinction between information and commentary, honesty, respect and tolerance, the primacy of recipient's good as well as freedom and responsibility. The signatories of the Charter have also appointed the Council to guard the above principles. Furthermore, media companies and journalist associations have established their own codes of ethics which complement the principals of the Charter. Now, at the beginning of the third decade of the twenty-first century, Poland has a new generation of journalists and 30 years of experience in dealing with a democratic free media system. The press law and the codes of ethics are reflecting the main values of the Social Responsibility Theory of the Press. As a researcher and journalist with 12 years of professional experience, I realised that this is a

\footnotetext{
${ }^{6}$ The only exception was a few magazines owned by the Catholic Church which used to have some margin of freedom.

${ }^{7}$ Siebert F., Peterson T., Schramm W. (1956), Four Theories of the Press, University of Illinois Press, Chicago, p. 2.

${ }^{8}$ Bajka Z. (2000), Dziennikarze lat dziewięćdziesiq̨tych. Zeszyty Prasoznawcze, vol. 3-4.
} 
Ethics and principles of Polish journalists. Quantitative and qualitative research.

perfect moment to verify whether or not these principles are respected by journalist and how Polish journalists understand the rules which they are obliged to obey.

\section{Polish journalists towards media ethics. Results of quantitative and qualitative} research.

\section{Methodology}

The data was gathered during two independent studies. The first was a survey consisting of 40 questions that concerned different aspects of journalist standards and ethics. There was a correlation between the questions and the assumptions of the Social Responsibility Theory of the Press (self-regulation, adhering to the codes of ethics, reliability, honesty, freedom, and objectivity). The research was conducted between April and June 2018. The link to the online survey was sent directly to the journalists, editors-in-chief, and editorial secretaries. Finally, 202 people from the news media industry participated in the study (among them: 40,1\% - TV journalists, 16,3\% - radio journalists, 15,8\% - internet journalists, 13,9\% - magazine journalists, $10,9 \%$ - daily newspapers journalists, $3 \%$ - others). The sample consists of $37,1 \%$ women and $62,9 \%$ men of different ages, education levels, and professional experience. The principal aim of the study was to answer the following questions:

- Is the journalists' community agreed or divided over legal and ethical norms and professional standards?

- Which professional standards are not respected, and to what extent?

The second study was made up of individual in-depth interviews with 14 journalists (seven women and seven men) covering news, sports, fashion, music, and technology. The interviews were conducted face to face. All of the conversations were recorded and transcribed. The anonymity of the interviewees was necessary to obtain honest and credible answers. The first part of the interview concerned the current state of journalism in Poland, the assessment of adhering to professional standards, the problem of fake news, media objectivity, and the differences between younger and older journalists. In the second part, the participants should have evaluated nine situations in terms of ethics and journalistic skills. Some of these situations had actually occurred and aroused various controversies in society; some were hypothetical but very probable. This study aimed to answer the following research questions: 
Ethics and principles of Polish journalists. Quantitative and qualitative research.

- What is the current state of journalism in Poland?

- Why do some journalists fail to comply with the legal and ethical standards of this profession? In which situations?

- What is the influence of the external factors on the obeying legal and ethical standards by journalists?

- Does technological progress affect compliance with these standards?

\section{Results}

\section{Self-regulation}

As mentioned above, there are two principal sources of ethical norms for journalists: law and codes of conduct. The Polish Press Law Act obliges media to realize the right of citizens to reliable information (Art. 1). The press is obliged to a true representation of occurring events (Art 6). The journalist's task is to serve society and the state and to act in accordance with work ethics and principles of community life (Art. 10). A journalist is obliged to exercise due diligence and accuracy during the collection and usage of the press material, especially to check compliance with the truth and indicate the source and to protect the personal interests and interests of informants acting in good faith and other entrusting people (Art 12) ${ }^{9}$. Also, hidden advertising to achieve material or personal gains is forbidden. Journalists can find some additional regulations in the Broadcasting Act, such as the obligation to protect children or anti-discrimination rules. In summary, Polish lawmakers did not impose many obligations on media workers. Most of the ethical issues are regulated in editorial guidelines or codes of conduct adopted by several journalists' associations. Participants of the survey answered a few questions concerning the self-regulation process:

Does your news company have a written code of ethics?

Yes $49,8^{10}$ | No 26,4 | Don't know 23,9

\footnotetext{
${ }^{9}$ Garczewska A. (2017), Translation of Polish Press Law Act, Law and Administration in Post-Soviet Europe, Volume 4: Issue 1.

${ }^{10}$ The data hereinafter presented in percentage.
} 
Ethics and principles of Polish journalists. Quantitative and qualitative research.

Do you know the code of ethics of your news company?

Yes 56,4 | No 22,3 | N/A 21,3

Do you think that the code of ethics is followed by employees in your company?

Yes 17,4 | Rather yes 34,8 | Don't know 13,4 | Rather No 7 | No 4 | N/A 23,4

The most important conclusion from this part of the survey is that only half of the journalists admit that their news company has a written code of ethics. It means that the rest of the participants do not know the document or do not have access to it. Only 17 per cent of journalists are certain that the code of ethics is followed by their co-workers. That raises a question about the knowledge of the principals among the journalists.

\section{Collection and usage of information.}

The survey contained several questions and statements regarding the issue of collection and usage of information. I asked about the reasons for choosing stories and ways of reporting them.

When choosing the stories that I would like to report, I try to determine whether or not the knowledge about them is essential to my audience.

Always 20,8 | Usually 57,9 | Sometimes 18,3 | Seldom 2,5 | Never 0,5

I believe that delivering reliable news to the audience is more important to my company than its interests (e.g. Economic)

Yes 28,4 | Rather yes 40,8 | Don't know 7 | Rather no 10,4 | No 3,5 
Ethics and principles of Polish journalists. Quantitative and qualitative research.

I believe that my news company exaggerates the sensational character of the stories just to gain a broader audience.

Yes 14,9 | Rather yes 27,9 | Don't know 6,5 | Rather no 34,3 | No 16,4

The results suggest that journalists and their news companies usually put the good of the audience before their own interests. They also admit that sometimes the sensational character of the news is a method of attracting the audience.

Concerning the problem of disinformation in modern society, I decided to ask participants of the survey about the verification information standards.

I confirm the information given by other media in a second source.

Always 50,5 | Usually 37,1 | Sometimes 10,9 | Seldom 1,9 | Never 0

I confirm the information of the Polish Press Agency in a second source.

Always 19,3 | Usually 30,7 | Sometimes 21,3 | Seldom 22,8 | Never 5,9

I confirm the information published in social media by an institution or a company in an official source.

Always 44,6 | Usually 32,2 | Sometimes 17,8 | Seldom 5 | Never 0,5

I confirm the information published in social media by public figures, politicians, and spokespersons in an official source.

Always 36,3 | Usually 36,8 | Sometimes 18,4 | Seldom 7,5 | Never 1 
Ethics and principles of Polish journalists. Quantitative and qualitative research.

I confirm the information published in social media by private persons in an official source.

Always 75,2 | Usually 17,3 | Sometimes 4,5 | Seldom 2 | Never 1

I confirm in at least two sources the information I have obtained.

Always 32,7 | Usually 50,5 | Sometimes 14,4 | Seldom 2,5 | Never 0

I wait before publishing information when its confirmation has been delayed.

Always 40,5 | Usually 42,5 | Sometimes 15,5 | Seldom 1,5 | Never 0

I refrain from publishing the information just because I have not confirmed it in another source.

Always 17,6 | Usually 31,2 | Sometimes 39,7 | Seldom 9,5 | Never 2

All of the participants who did not choose the "always" option were asked to answer additional questions:

I make unofficial information public, without confirmation from another source.

Always 0 | Usually 5,4 | Sometimes 34,9 | Seldom 41,6 | Never 18,1

I inform the audience that the information I am providing is unofficial.

Always 84,3 | Usually 10,8 | Sometimes 3 | Seldom 0,6 | Never 1,2 
Ethics and principles of Polish journalists. Quantitative and qualitative research.

I consult with my supervisor, editor in chief before publishing unofficial information.

Always 62,9 | Usually 22,2 | Sometimes 10,8 | Seldom 2,4 | Never 1,8

Double-confirmation is supposed to be a golden standard for professional journalists. The study shows this rule is usually respected but not always. What is particularly significant that only one-third of the participants always double-check the news they have obtained. Some of them do not inform the audience that the information is unofficial. It suggests that the journalist's misconduct can be among the reasons for the growing fake news problem.

In some situations, journalists may use advanced and often illegal methods to gather information. I asked participants if they agree with these practices and to what extent. The respondents mostly approve of it.

Do you believe that a journalist has the right to use provocation to reveal illegal actions?

Yes 55 | Rather yes 35 | Don't know 4 | Rather no 5 | No 1

Do you think that a journalist has the right to use wiretapping or hidden cameras to obtain information?

Yes 44 | Rather yes 35 | Don't know 6,5 | Rather no 9 | No 5,5

\section{Responsibility}

The following statements regard the problem of accountability and honesty in connection with the publication of false or imprecise information.

I have consciously disclosed untrue information to the public.

Never 97,5 | Once 1 | Few times 1,5 | Often 0 
Ethics and principles of Polish journalists. Quantitative and qualitative research.

I have published untrue information unknowingly and unintentionally.

Never 46 | Once 21,8 | Few times 32,2 | Often 0

I correct publicly false or imprecise information that I provided.

Always 35,3 | Usually 17,4 | Sometimes 5,5 | Seldom 1,5 | Never 3 | N/A 37,3

I react when my news company publishes false information.

Always 58,4 | Usually 24,8 | Sometimes 12,4 | Seldom 3 | Never 1,5

The participants admit that they rarely publish untrue information unknowingly or unintentionally. A disturbing fact is that only 35 per cent of the respondents always correct the false information they have provided. It suggests that a significant part of journalists do not take responsibility for the consequences of their misconduct.

\section{Freedom}

Formally, freedom of the media is a principal granted by the Constitution and repeated in the Press Law Act. Notwithstanding, journalists may often experience a different kind of influence from the government, politicians, public and private companies, or supervisors.

I believe that I am able to perform my journalistic profession freely.

Yes 41,8 | Rather yes 41,8 | Don't know 4,5 | Rather no 9,5 | No 2,5

I believe that the government interferes with the content of information published by my news organisation. 
Ethics and principles of Polish journalists. Quantitative and qualitative research.

Yes 10,9 | Rather yes 10,4 | Don't know 6,4 | Rather no 31,2 | No 41,1

I believe that the government may limit the freedom of the press in the event of a threat to public order.

Yes 1,5 | Rather yes 4,5 | Don't know 3 | Rather no 21,3 | No 69,8

I believe that advertisers influence the content of information published by the organisation.

Yes 10,4 | Rather yes 13,4 | Don't know 11,9 | Rather no 34,7 | No 29,7

I believe that journalists must follow the program policy of the news organisation.

Yes 13,9 | Rather yes 33,3 | Don't know 17,9 | Rather no 19,4 | No 15,4

I believe that the supervisor or the editor has the right to interfere with the stories that I have published.

Yes 14,5 | Rather yes 42 | Don't know 6,5 | Rather no 30 | No 7

Do you believe that a journalist has the right to refuse to cover an event that concerns values that are against his own views (e.g. gay pride or demonstrations against abortions)?

Yes 27,7 | Rather yes 11,9 | Don't know 5 | Rather no 24,8 | No 30,7

The study shows that journalists are strongly divided over the assessment of the level of freedom they have. When asked about more general opinion, they usually say that they can perform journalism freely. But the answers to more specific questions show that the respondents experience both external and internal influences that may interfere with their work. 
Ethics and principles of Polish journalists. Quantitative and qualitative research.

\section{Impartiality}

Impartiality is one of the most difficult issues to define. What does it mean to be "impartial"? Is objectivity not just a utopian idea, impossible to apply in reality? The survey consists of several statements concerning this problem.

I believe that a journalist has the right to reveal his political views.

Yes 12,4 | Rather yes 15,8 | Don't know 10,9 | Rather no 27,7 | No 33,2

I believe that a journalist has the right to reveal his point of view on important social issues.

Yes 24,3 | Rather yes 23,8 | Don't know 7,4 | Rather no 25,7 | No 18,8

I believe that a journalist has the right to reveal his religious beliefs.

Yes 31,2 | Rather yes 22,3 | Don't know 14,9 | Rather no 16,8 | No 14,9

I believe that the journalist has the right to participate in demonstrations.

Yes 15,3 | Rather yes 16,8 | Don't know 8,4 | Rather no 27,2 | No 32,2

I believe that a journalist has the right to post on social media information that may reveal his political views.

Yes 21,8 | Rather yes 24,3 | Don't know 7,4 | Rather no 27,7 | No 18,8

I believe that a journalist has the right to share in social media links to websites promoting values important to him (religious, social, ethical, and political).

Yes 34,2 | Rather yes 28,2 | Don't know 10,9 | Rather no 17,8 | No 8,9 
Ethics and principles of Polish journalists. Quantitative and qualitative research.

The results show that there is no unanimity among the journalists in the matter of impartiality. More than half of the respondents are against revealing journalists' political views and participating in demonstrations. But they are more likely to share their views on social or religious issues (especially on social media).

\section{Bribery}

Hereinafter the bribery means direct or indirect material influence on media reporting such as accepting bribes and paid material disguised as news stories or extorting money either for publishing favourable stories or for not publishing damaging ones. This also refers to accepting gifts and placing advertisements in favour of private or political interests ${ }^{11}$.

Do you believe that a journalist has the right to accept gifts from companies, PR agencies, organizations of press conferences and meetings?

Yes 14,9 | Rather yes 22,8 | Don't know 10,9 | Rather no 28,2 | No 23,3

Do you think that a journalist has the right to write an article for a fee, at the request of a company or an institution?

Yes 13,4 | Rather yes 17,3 | Don't know 7,4 | Rather no 22,3 | No 39,6

Do you think that your news organisation avoids publishing information that could harm the interests of advertisers?

Yes 14,5 | Rather yes 22,5 | Don't know 23,5 | Rather no 28 | No 11,5

\footnotetext{
${ }^{11}$ Fighting corruption in the media, Association of Accredited Public Policy Advocates to the European Union http://www.aalep.eu/fighting-corruption-media
} 
Ethics and principles of Polish journalists. Quantitative and qualitative research.

Do you think that the information presented by your news organisation depends on the preferences of the recipients?

Yes 28,9 | Rather yes 48,3 | Don't know 8,5 | Rather no 11,4 | No 3

The study shows that part of the respondents accepts practices that can be seen as a form of bribery. It casts a pall over the honesty and reliability of journalists and the quality of their work.

\section{Conclusions and introduction to the qualitative study}

Even though the legal and ethical frameworks are the same for all journalists, the study shows that there is no unanimity among the respondents in assessments of those rules. 36 out of 40 questions or statements in the survey had the possible answers: Yes/Rather yes/Don't Know/Rather No/No or Always/Usually/Sometimes/Seldom/Never. After combining the answers ('Yes' with 'Rather Yes' and 'No' with 'Rather No' etc.), there were only 12 questions or statements where more than 80 per cent of respondents were agreed. In the assessment of the 24 issues, journalists were divided or strongly divided. The participants disagreed on the principles such as verification information standards (e.g. double-checking sources) or impartiality (e.g. revealing one's political views or attending demonstrations). Also, the behaviours that may be seen as a form of corruption were among the issues dividing respondents. The extremely significant fact is that almost half of the journalists do not know or do not have access to the company's code of conduct. All of that suggests that the level of adhering to the ethical rules is very low.

Quantitative research like this one can pinpoint the problem but cannot deliver any credible answer about the reasons for this situation. That's why I decided to conduct complementary qualitative research. The answers from 14 journalists who took part in the in-depth interviews helped me to identify the main reasons for lowering ethical standards. 
Ethics and principles of Polish journalists. Quantitative and qualitative research.

\section{In-depth interviews results}

Due to limited size of this article, I decided to present only the main conclusions from this study. A full description with numerous quotes and examples was published in my book "Dziennikarzy portret własny"12.

The first research question was: what is the current state of journalism in Poland? The image projected by the respondents is not optimistic. The gravest sins of modern journalism are the lack of knowledge, the lowering of the ethical standards, being under pressure, corruption, politicization, commercialization, and the removal of experienced journalists. The interviewees have a negative forecast for the future as well. They believe that the digression of this profession will continue and the meaning of the ethical standards will be less significant.

The second research question was: why do some journalists fail to comply with the legal and ethical standards of this profession? The respondents pointed out a few reasons for this. First, there are more and more journalists without experience who were hired because of their political connections. Second, the most experienced journalists are replaced with younger ones so they cannot share their knowledge about professional standards. Third, the external influence (from politicians or private organisations) increases pressure on journalists so they cannot perform their job freely and accordingly to the standards. The interviewees gave various examples of concrete situations when they needed (or wanted) to resign from adhering to the ethical standards.

The third question was about the influence of external factors on the obeying legal and ethical standards by journalists. The respondents believe that politicization and commercialization of the media are the main external factors that influence journalists. The impact of politics is usually connected with the public media that are strongly dependent on the ruling party. The pressure on journalists makes reliable and impartial reporting almost impossible. The private media companies that want to balance public media coverage can also be a propaganda tool and they are no longer an impartial source of information. The examples of growing politicization of media are: mixing the news with commentary, mixing the role of journalists and commentators, revealing political views, and attending demonstrations. The interviewees

\footnotetext{
${ }^{12}$ You can find more details on the publisher website www.libron.pl or on my ResearchGate profile: https://www.researchgate.net/profile/Michal_Chlebowski
} 
Ethics and principles of Polish journalists. Quantitative and qualitative research.

have also pointed out the connections between business and the media. The private media rely on commercials. In this field, there are various ethical abuses such as avoiding publishing information that could present the advertiser unfavourably. The respondents cited many examples of such situations in which some information relevant to the recipients did not reach them because the interest of a private company was protected. The other problem is that media companies want to multiply the profit from advertising so they use some unethical methods to attract the attention of the audience. Finally, journalists themselves make unethical decisions, such as accepting benefits from advertisers that influence their coverage.

The study answered also the last research question about the influence of technological progress. The interviewees believe the development of 24-hour news channels and worldwide access to the internet have impacted journalism. There is less time to verify and deliver the news to the audience. The role of the journalism itself has been limited. That has resulted in the fast-spreading fake news. New technologies are also among the reasons for replacing experienced journalists with young people with more innovative skills.

\section{Conclusions}

Both studies presented in this article prove that ethical journalism in Poland is in crisis. In theory, the Press Law Act and existing codes of ethics are a great source of values and professional guidelines for media workers. But these rules are not commonly accepted and respected by all journalists. Even the principles like verification information standards, reliability, impartiality, or truthfulness are not shared values. Journalists experience considerable pressure from politicians and private companies (especially advertisers). The public media are under complete control of the government so the journalists cannot perform their job freely and accordingly to professional standards. Journalists working in private companies have greater freedom but they also experience internal and external pressure disturbing their job. That may result in the poorer quality of the news delivered to the audience, an increasing amount of fake news, decreasing trust in media, and finally, destroy the public debate.

In the report of the Commission on Freedom of the Press, one of the members points out that: Inseparable from the right of the press to be free has been the right of the people to have a 
Ethics and principles of Polish journalists. Quantitative and qualitative research.

free press. But the public interest has advanced beyond that point; it is now the right of the people to have an adequate press ${ }^{13}$. The results of these studies should alert journalists, editors, owners of media companies, and scholars. There is much work still to do if we want to have socially responsible media that adequately fulfil their role in society.

\section{References:}

Bajka Z. (2000), Dziennikarze lat dziewięćdziesiq̨tych. Zeszyty Prasoznawcze, vol. 3-4.

Bates S. (2018), Media Censures: The Hutchins Commission on the Press, the New York Intellectuals on Mass Culture, International Journal of Communication vol. 12, pp. 47844801.

Chlebowski M. (2020), Dziennikarzy portret własny. Libron, Warsaw.

Fighting corruption in the media, Association of Accredited Public Policy Advocates to the European Union http://www.aalep.eu/fighting-corruption-media

Garczewska A. (2017), Translation of Polish Press Law Act, Law and Administration in PostSoviet Europe, Volume 4: Issue 1.

Hocking W.E. (1947), Freedom of the press: a framework of principle. The University of Chicago Press, Chicago.

Siebert F., Peterson T., Schramm W. (1956), Four Theories of the Press, University of Illinois Press.

\footnotetext{
${ }^{13}$ Hocking W.E. (1947), Freedom of the press: a framework of principle. The University of Chicago Press, Chicago.
} 